\title{
A Charing Cross Printer, Robert Wyer.
}

$W^{\text {ITHIN a stone's throw of what is now Villiers Street, }}$ Charing Cross, once stood the noble town residence of the Bishops of Norwich. In aftertines the house had an eventful history, passing successively through the hands of the Dukes of Suffolk, the Archbishops of York, and the Dukes of Buckingham. It was for years the home of the Chancellors of England, and was the birth-place of Francis Bacon.

But at the beginning of the sixteenth century it was in the hands of its original founders, the Bishops of Norwich. Its lands stretched down to the river, and amongst the tenements belonging to it was one over which hung the sign of St. John the Evangelist. This house was occupied by a printer, named Robert Wyer, one of the busiest of the few masters of the craft then in England.

Scanty indeed has been the fame meted out to the memory of Robert Wyer. Scarcely anyone knows that such a man ever existed. About 12 years ago a clergyman, in the parish of St. Martin-in-the-Fields, wrote an account of the parish in the olden time, but seems to have been entirely ignorant that any printer lived in it. Readers of Thornbury and Walford's Old and New London may search in vain for any notice of him.

There is a brief account of him in the various editions of Ames' Typographical Antiguities, followed by a highly useful study of the books which he printed. Since the last revision of that work our sources of knowledge have greatly increased, many extensive and valuable libraries have gone to the hammer; bibliographical research has become keener, and many hitherto unknown works printed by Robert Wyer have come to light. On the other hand, the materials at hand for dealing with his personal history are of the very scantiest description, and this accounts, in a great measure, for the smalt notice he has hitherto received. To begin with the rent rolls of the London property of the bishopric of Norwich have been either lost or destroyed, for they cannot be traced, while such of the subsidy rolls as relate to the parish of St. Martin-in-the-Fields yield no information about him. Hence, it is impossible to say when he first went to live in " the Bishop of Norwiche's Rentes." 
Nor is there any authentic record of his death. He was not a member of the guild of stationers, and the fact of only a few of his works having a date still further increases the difficulty of finding out anything about him.

Nevertheless, there is much doubt, ignorance, and error in the scanty record of Ames' that can be cleared away, and if in doing so the attention of the learned can be directed to the life-work of this very remarkable printer some good will have been done.

In the first edition of Ames', in the notice of Robert Wyer, there appeared a footnote respecting a work, entitled, Expositiones torminorum legum Anglonum, dated I527, and bearing a device similar to Wyer's, but believed to be, on what authority it is not stated, from the press of one, John Butler or Boteler, who carried on his business at the sign of St. John the Evangelist in Fleet Street. From this it was argued that $\mathrm{Wyer}$ might have been Butler's pupil, and had adopted his sign when setting up for himself.

Of Butler's work it was said only one other specimen was known, namely, Parnulorum Institutio ex Stanbrigiana Collectione. Since then two other works have been traced to Butler's press. The first is a fragment of a poem, entitled, The Ieasto of Sir Gawayne. On the last of the four quarto leaves of the copy in the Lambeth Palace Library are the words, "Imprynted at London in Flete Street at the Sygne of Saynt Johan Evangelyste by me, Johan Butler." The second is a copy of Stephen Hawes' The Conversyon of swerers, noticed in the catalogue of the Huth Library.

But the theory of a possible connection between Wyer and Butler is greatly strengthened by the discovery in the Bodleian Library of another of Stanbridge's works printed by Wyer at Charing Cross. That work is entitled Vocabula Magistri Stabrigii sua salte editions edita, and bears the colophon, "Imprynted by me, Robert Wyer, dwellynge at the sygne of Saynt Johan Evangelyste in Saynt Martyn's parysshe, besyde Charynge Crosse."

This work has no date, but was unquestionably one of the first that issued from Wyer's press. This would put it about the year 1530 .

In the year 1536, William Rugge, abbot of St. Benet, Hulme, was made Bishop of Norwich, and immediately parted with all the lands of his bishoprick (including, of course, the London estates) to King Henry the VIII. in exchange for lands belonging to the Abbey of Hulme and priory of Hickling. In the same year the king transferred Norwich House in the 
Strand to one of his powerful nobles, Charles Brandon, Duke of Suffolk, in exchange for a house in Southwark. And from that time forward, Wyer, when he gave any definite address at all, stated that he lived "besyde the Duke of Sufolkes Place" or " in the Duke of Sufolkes Rentes."

It is important to bear this change of Wyer's address in mind, because it helps the bibliographer to assign certain books to certain periods, instead of making wild guesses at dates that prove afterwards to have been wide of the mark.

Thus, then, all the books printed by Robert Wyer and bearing the imprint of the Bishop of Norwiches Rentes, were printed before the year 1536 ; and all those that have the imprint of the Duke of Suffolk's Place, were printed after that year. What confirmation is there of this ? First of all, two of the few books that issued from the St. John the Evangelist, with a date, viz., The Golden Pystle, of Richard Whyteforde, printed in 1531, and Garard's Interprotacyon . . . . of the Masse, printed in 1532, both bear the imprint " in the Bishop of Norwich's Rentes."

But two stronger proofs of the value of bearing in mind this change in the ownership of Norwich House, is to be found in the catalogue of the British Museum Library. In that library is a copy of the Assize of Bread and Ale, printed by Robert Wyer; and the authorities have given the probable date of printing as 1528 .

But on turning to the colophon it is found that the book was printed in the Duke of Sufolkes rentes, is., after 1536, and from internal evidence, a still nearer approach can be made to the actual date of printing. Incorporated with the book is the $A$ ssise of Wood and Cole, in which is quoted at length a Statute of Parliament that was to take effect from the Feast of the Purification in the year "a thousande fyve hundred, forty and three."

The second instance is that of a work entitled The $C$ Hystoryes of Troy, printed by Robert Wyer, according to the British Museum authorities, about the year 1530 . But here again the colophon proclaims that the work' was printed in the Duke of Sufolke's Rentes, or, after ${ }_{1536 .}$ By this means no less than thirty-eight works printed by Wyer can be assigned to periods. This, no doubt, still leaves the bulk of the books known to have been printed by him unaccounted for. In these cases the colophon merely says: "Imprinted by me, Robert Wyer," or 
"Imprynted by me, Robert Wyer, dwellinge in St. Martyn Parysshe, in the felde besyde Charynge Crosse," or some such vague description. But, at any rate, it brings us nearer to the truth, and in course of time there is no reason why many others should not be cleared from the mists of doubt that hover round them.

To pass now to another matter respecting Robert Wyer, about which error and ignorance have long lingered. At the time of the late revision of Ames' ${ }_{k}$ work, the latest date found in any book printed by Wyer was I542, and the work was Vaughan's Dialogwe defensive of Womer. It was, therefore, assumed that he died, ot at all events ceased to print in that year.

There is abundance of evidence, however, to prove that such was not the case, that, in fact, he was printing as late as the year 1556 , and it was not until the year 1560 that he was succeeded at the sign of the St. John the Evangelist, by Thomas Colwell, a freeman of the newly-formed Stationers' Company. There are Almanacs and Prognostications for the years 1555 and 1556. In another book there is an author's preface dated from Thavies Inn, Holborn, I550. Again, he is found printing for a brother craftsman, Richard Kele, of the Long shoppe in the Poultry, whose earliest dated work was 1545 .

Here, then, we laave a life-work of thirty years. That it was a busy life is proved beyond a doubt by the number of works that have come down to us from his press, for it must be remembered that printing was a much longer process then than it is to-day.

Passing these works in review, and noting their varied character, the style :of the printing and the quality of the paper, it is not hard to form a theory respecting !Robert Wyer and his work. Herbert somewhat contemptuously dubbed him a printer for the ballad stalls.

True, we do not find sumptuous Bibles, or choice editions of Chaucer turned out by Wyer. He was the printer for the people and all honour to him for it. Most of his publications were little brochures, roughly printed, coarsely bound and illustrated with rude woodcuts, but they shew us what were the books that were read in the sixteenth century by the general public. Instead of treating them and their printer as beneath notice or remembrance, they should attract attention as specimens of a very curious literature. 
All was grist that came to the mill of Robert Wyer. Astronomy, botany, geography, divinity, medicine, a romance, a play, with a sprinkling of law and history.

Moreover, the knowledge conveyed through these little volumes was the best that could be found in those days. The astronomy came from the writings of Aristotle and Ptolemy; the botany included Macer's Herball; in geography the name of Ptolemy is met with again. The authors in divinity included Thomas à Kempis, Martin Luther, William Hunnis, and lesser men, such as Richard Whytforde, brother of Sion and Friar Garard of the Order of Observants. In medicine, the name of the great physician of the day, Andrew Borde, stands out prominently as the author of The Dietary of Helthe, The Boke to Leme a Man to be Wyse in Buyldynge of his Howse, and The Seeing of Urines.

As an instance of how misleading a printer's error may be, it may be noted here that Herbert, in his addition of Ames', declared that he had in his possession a copy of The Dietary of Helthe printed by Thomas Colwell in 1542. It has already been shown that Colwell did not succeed Wyer until 1560 , and the copy in question was not printed until 1562 .

Amongst Wyer's publications are several "curiosities of literature." Foremost amongst these must be ranked a work bearing the following title:-Here begynneth a lytell boke of the xxiiii. stones pryncipelles that profyteth most to man's bady. After reciting the 24 stones it goes on to relate some of the most astonishing fables respecting their origin and discovery.

Then again there is the Treatyse Answerynge the Boks of Berdes, compyled by Collyn Cloute, dedycated to Barnarde Barber dwellynge in Banbery. On the last leaf are the words, "Barnes in the defence of the Berde."

Wyer, however, did not confine himself to ballad or stall literature, and he turned out one or two works, that for clearness of type, \&c., were equal to anything turned out by the brethren of the craft in Fleet Street. As a specimen of printing in the I6th century his copy of The Defence of Peace, a work translated by William Marshall from Marsilius de Padua, may justly take rank as a very fine work.

It is clear, from the above rough sketch of his work, that Robert Wyer was by no means an obscure man, but deserves to rank as high as many of his contemporaries, and it is much to be regretted that so little is known of his personal history. As 
one of the few printers who worked at the West End of London, long after Wynkyn de Worde had settled within Temple Bar, he certainly deserves notice in any work that professes to be a history of London.

Henry R. Plomer.

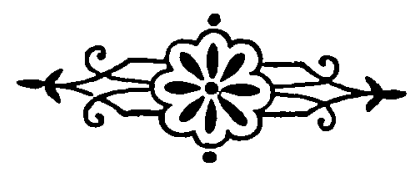

